1969

\title{
American Jurisprudence Between the Wars: Legal Realism and the Crisis of Democratic Theory
}

Edward A. Purcell Jr.

New York Law School, edward.purcell@nyls.edu

Follow this and additional works at: https://digitalcommons.nyls.edu/fac_articles_chapters

Part of the Jurisprudence Commons, and the Law and Psychology Commons

\section{Recommended Citation}

75 American Historical Review 424 (1969)

This Article is brought to you for free and open access by the Faculty Scholarship at DigitalCommons@NYLS. It has been accepted for inclusion in Articles \& Chapters by an authorized administrator of DigitalCommons@NYLS. 


\section{OXFORDJOURNALS}

OXFORD UNIVERSITY PRESS

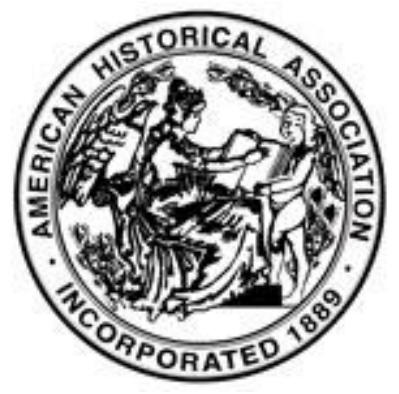

American Jurisprudence between the Wars: Legal Realism and the Crisis of Democratic Theory

Author(s): Edward A. Purcell, Jr.

Source: The American Historical Review, Vol. 75, No. 2 (Dec., 1969), pp. 424-446

Published by: Oxford University Press on behalf of the American Historical Association Stable URL: http://www.jstor.org/stable/1849692

Accessed: 13-12-2017 11:33 UTC

JSTOR is a not-for-profit service that helps scholars, researchers, and students discover, use, and build upon a wide range of content in a trusted digital archive. We use information technology and tools to increase productivity and facilitate new forms of scholarship. For more information about JSTOR, please contact support@jstor.org.

Your use of the JSTOR archive indicates your acceptance of the Terms \& Conditions of Use, available at http://about.jstor.org/terms

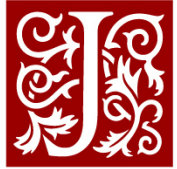

Oxford University Press, American Historical Association are collaborating with JSTOR to digitize, preserve and extend access to The American Historical Review 


\title{
American Jurisprudence between the Wars: Legal Realism and the Crisis of Democratic Theory
}

\author{
Edward A. Purcell, JR.
}

DURING the 1930's the American legal profession became the forum for one of the most bitter and sustained intellectual debates in the nation's history. A new generation of legal scholars, inspired by Justice Oliver Wendell Holmes, Jr., and attempting a scientific study of law, was developing a sweeping critique of American jurisprudence that went far beyond the criticisms of such sociological jurists as Roscoe Pound and Benjamin N. Cardozo. By I930 their stinging attacks on established legal conceptions had alarmed traditional-minded jurists and within a few years had raised distressing questions from the standpoint of democratic theory about the nature and basis of law. The frightening challenge of totalitarianism in the late thirties moved the debate out of the realm of mere juristic speculation and gave it a tone of urgency and crisis.

The new legal criticism developed out of the same intellectual environment that generated new attitudes throughout American intellectual life. The increasing prominence of the physical sciences, at least since the time of Charles Darwin, had been convincing more and more individuals that knowledge of the physical world and of human beings themselves could only be attained through the use of the scientific method. By the beginning of the twentieth century the pragmatism of William James and especially of John Dewey had provided a broad philosophy that attempted to explain the human and social meaning of science and that suggested how the scientific method could be employed to understand and resolve human problems on all levels. Large numbers of American thinkers in many diverse fields began to adopt a more empirical, experimental, and relativistic attitude toward the problems and guiding assumptions of their disciplines. The impact of science and pragmatism, together with the desire for the improvement of man's social and political life that many intellectuals shared, brought new vitality, ideas, and methods to the expanding social sciences.

Through such approaches as functionalism and behaviorism, American psychologists were striving to make their discipline experimental; the new science began to play an increasingly prominent role in the social thought of the twentieth

- After receiving his doctorate in 1968 from the University of Wisconsin, where he worked under Irvin G. Wyllie, Mr. Purcell taught for two years in an experimental interdisciplinary program at the University of California, Berkeley. He is now a visiting assistant professor at the University of Missouri. His essay, "Ideas and Interests: Businessmen and the Interstate Commerce Act," Journal of American History, LIV (Dec. 1967), won the Organization of American Historians' Pelzer Award for 1967 . 
century. By offering to explain the sources and nature of human behavior, psychology promised to bring the elusive human factor under control and to enable social scientists to make their work wholly empirical. "The importance of the rapid rise of psychology in recent years," explained Edward S. Robinson, a psychologist working with the Yale University Law School, "is that it supplies a background for a natural science of society which has hitherto been lacking." Because psychology seemed to answer an intellectual need that had grown acute by the twenties, many social scientists turned toward its discoveries and theories with renewed hope and enthusiasm.

Rejecting the prescriptive theories of classical economics, such scholars as Thorstein Veblen and Wesley Mitchell studied production and distribution as problems in the institutional behavior of individuals and groups. "Economics," Mitchell declared, "is a science of human behavior." Charles Merriam urged his fellow political scientists to apply the discoveries of psychology and the other social sciences to the study of politics, and along with many of his colleagues produced closely detailed studies of the actual operations of governments, politicians, and pressure groups. Bronisław Malinowski refined techniques of careful observation and description in anthropological field work and developed a theory of society based on the functional interrelationships of all parts of a culture. ${ }^{3}$ Throughout those disciplines the new empirical, experimental approach emphasized the importance of analyzing social phenomena in terms of functions and behavior.

Along with the primary reliance upon scientific methods came a pervasive epistemological and ethical relativism. Because valid knowledge had to be based on empirical evidence, all a priori absolutes were unproven and unprovable. All knowledge was necessarily tentative and subject to change. Since science supposedly dealt only with objective facts and was morally neutral, the one practically reliable method of reaching truths was inoperative where questions of an ethical nature were concerned. Although a few men such as Dewey maintained that the scientific method could develop and substantiate moral values, most scholars in the interwar decades were not convinced. The empirical documentation of widespread cultural relativism by anthropologists like Ruth Benedict confirmed the relativistic trend, as did the analyses of the nature of historical knowledge by such scholars as Carl Becker and Charles Beard. By the early thirties both Beard and Becker were arguing that historical judgments could never be truly objective because they were based on partial evidence, were not subject to experimental testing, and were warped by the desires and beliefs of the historian. Value judg-

1 Edward S. Robinson, Law and the Lawyers (New York, r935), 49.

2 Wesley Clair Mitchell, "The Prospects of Economics," in The Trend of Economics, ed. Rexford G. Tugwell (New York, I935), 22.

3 For examples, see Charles Merriam, New Aspects of Politics (Chicago, 1925); Bronisław Malinowski, "Introduction," in Robert I. Hogbin, Law and Order in Polynesia-A Study of Primitive Legal Institutions (2d ed., Hamden, Conn., 196r). 
ments, Beard concluded along with most of his contemporaries, "cannot be 'proved' by reference to historical occurrences or anything else."

While the basic attitudes of an empirical and relativistic social science spread throughout most of American intellectual life, they penetrated legal thinking slowly and haltingly. As late as the 1920's the predominant legal theory still claimed that judicial decisions were made on the basis of rules and precedents defined historically and applied mechanically. The eighteenth-century concept of natural law served vaguely as the moral foundation for legislative and judicial actions, while Sir William Blackstone's statement of the common law provided many of the supposed first principles on which judicial decisions were based. The old legal theory claimed that reasoning proceeded syllogistically from those rules and precedents through the particular facts of a case to a clear decision. The sole function of the judge was to discover the proper rules and precedents involved and to apply them to the case as first premises. Once he had done that, the judge could decide the case logically with certainty and uniformity. ${ }^{5}$

In spite of its established predominance, however, the old legal theory had already come under forceful attack by the beginning of the twenties. As early as I88I Justice Holmes, then a young lawyer in Boston, had published his famous study of the common law, which he placed in an evolutionary Darwinistic framework. Holmes argued that practical expedients, necessitated by the needs and conflicts of human society, were much more central to the development of law than were any logical propositions. The Common Law was, to use a congenial Holmesian metaphor, the first cannon shot in his fifty-year battle against the armies of legalistic formalism.

By 1897 the basic outline of his scientific, relativist attack was clear. Law was not an abstract problem of logic, but a practical question of social management. Judges did not in fact settle cases by deductive reasoning; rather they necessarily decided what was socially desirable according to their personal and class beliefs. Those beliefs, like all moral values, were wholly relative and determined by one's particular environment. The power of deductive logic and the ethical and social absolutes that the method claimed to establish were simply illusions that masked the actual working of the legal process. By the law, Holmes declared, he meant no metaphysical truths or grand moral principles such as a rationally knowable "natural law," but only "the incidence of the public force through the instrumentality of the courts." The lawyer's sole duty was to predict how the courts would use that force, and hence to advise his clients most effectively. Thus defining the

4 Charles A. Beard, The Discussion of Human Affairs (New York, 1936), Ir9-20; see also id., "Written History as an Act of Faith," American Historical Review, XXXIX (Jan. I934), 219-29; Carl L. Becker, "Everyman His Own Historian," ibid., XXXVII (Jan. 1932), 221-36; Ruth Benedict, Patterns of Culture (New York, 1934).

5 See Roscoe Pound's original attack, "Mechanical Jurisprudence," Columbia Law Review, VIII (Dec. 1908), 605-23; Edwin W. Patterson, Jurisprudence: Men and Ideas of the Law (Brooklyn, N. Y., 1953), 465-66; and Wilfred E. Rumble, Jr., American Legal Realism: Skepticism, Reform, and the Judicial Process (Ithaca, N. Y., 1968), 49-5I. 
law in empirical, behavioral terms, Holmes urged his colleagues to study "the operations of the law" rather than its phraseology or moral connotations. ${ }^{6}$

By the first decade of the twentieth century other scholars were beginning to follow Holmes's lead and to apply the insights of the new scientific, pragmatic outlook. John Chipman Gray, a professor of law at Harvard University, stressed the pre-eminent role of the individual judge as opposed to the logic of the law itself in deciding particular cases. Louis D. Brandeis, and later Felix Frankfurter, argued that judges must consciously consider the probable social results of their decisions. Scientific studies of social needs and problems, rather than syllogistic reasoning, should be the determining factor. To guide the judges in their assessment of those social results, both men employed briefs loaded with a maximum of sociological evidence and a minimum of logical argumentation. ${ }^{7}$

Much of the theoretical justification for the "Brandeis brief" came from the work of a young law professor at the University of Nebraska, Roscoe Pound, who wrote a series of articles showing the need for and relevance of a new sociological jurisprudence. "The sociological movement in jurisprudence," he explained in I908, "is a movement for pragmatism as a philosophy of law."8 Agreeing with Holmes that legal scholars must study the way laws operate in practice, Pound insisted that the overemphasis on logical uniformity and theoretical certainty that characterized much of the older approach often frustrated the just practical settlement of particular cases. Only by studying the social impact of legal principles and rules could men know whether the law in fact brought about the administration of real justice. While Pound and Holmes agreed on many points, especially on the mechanical and abstract nature of the older legal theory, Pound's greater emphasis on the ideal of justice conflicted with Holmes's more cynical view of moral values in the law. Ultimately that difference would be one of the central reasons for Pound's rejection of Holmes's disciples, who were to some extent also his own, in the 1930's.

It was thus in a rigid and formalistic profession that nevertheless had produced a Holmes and a Pound, and in a broader intellectual environment that recognized science as the method of reaching truth, that the so-called legal realists came of age. Of a sample of twenty-two of the most important new critics only five had been born before I880, while eight were born during the I880's, and nine after I890. By 1930 when their collective efforts were first termed "legal realism" their average age was still only forty-two. ${ }^{9}$ Thus the realists formed a younger genera-

6 Oliver Wendell Holmes, Jr., "The Path of the Law," in The Mind and Faith of Justice Holmes: His Speeches, Essays, Letters and Judicial Opinions, ed. Max Lerner (New York, 1943), 72, 76.

7 John Chipman Gray, The Nature and Sources of Law (2d ed., Boston, 1963), 99-101, 168-73. For the "Brandeis brief," see the account in Robert E. Cushman and Robert F. Cushman, Cases in Constitutional Law (New York, 1958), 580.

8 Pound, "Mechanical Jurisprudence," 609.

${ }^{9}$ Eighteen of the twenty-two were taken from Karl Llewellyn's initial identification of those whom he considered leading realists. (Karl N. Llewellyn, "Some Realism about Realism-Responding to Dean Pound," Harvard Law Review, XLIV [June 193I], 1222-64.) The eighteen are Underhill Moore, Herman Oliphant, Charles E. Clark, Llewellyn, Jerome Frank, Walter Wheeler Cook, Thomas Reed Powell, Leon Green, Max Radin, William O. Douglas, Hessel E. Yntema, Edwin W. Patterson, Arthur 
tion of scholars, less committed to what they regarded as the rigid ways of the past and more willing to follow new methods and ideas. Having grown up with the spread of the scientific outlook and the successful growth of the social sciences, they readily accepted a critical, empirical attitude and hoped to apply it to the study of the legal process. Facing the need to discuss the observed facts of judicial behavior, many of the realists turned toward psychological theory for a scientific framework within which to work.

While their pragmatic attitude made them hostile toward the older legal theory and their age put them in the position of a new generation ready to criticize established methods, the state of American law invited and even necessitated their devastating attacks. The inconsistencies between the practices of a rapidly changing industrial nation and the claims of a mechanical juristic system had grown so acute by the 1920's that in the minds of an increasing number of individuals the old jurisprudence could no longer justify and explain contemporary practice. It had become clear, Judge Cardozo declared in 1932, that "the agitations and the promptings of a changing civilization" demanded more flexible legal forms and demanded equally "a jurisprudence and philosophy adequate to justify the change." 10

At the same time even many of the strict proponents of the old jurisprudence had to admit that widespread confusion and uncertainty threatened the American legal system. Such a stalwart of orthodoxy as Elihu Root acknowledged that "the confusion, the uncertainty, was growing worse from year to year" and that as a result "the law was becoming guesswork." ${ }^{11}$ Root, like many other lawyers, found the cause of confusion primarily in the massive growth of case law during the previous decades. The whole case law system had, in fact, become unwieldy since the I870's when the National Reporter system was inaugurated. At that time the West Publishing Company had begun printing all federal court opinions throughout the United States, in addition to all higher and some lower state court decisions. By the beginning of the twentieth century the National Reporter system had turned the inevitably increasing number of cases into an avalanche of reported precedents that made it impossible for judges to stay properly informed. ${ }^{12}$ To their

L. Corbin, Wesley A. Sturges, Leon Tulin, Joseph F. Francis, Joseph W. Bingham, and E. G. Lorenzen. Biographical material was unavailable for two of Llewellyn's original twenty (Joseph C. Hutcheson and Samuel Klaus). Four other scholars (Walter Nelles, Thurman Arnold, Robinson, and Felix S. Cohen) have impressed me as significant contributors to realism and have been added for that reason. The list does not include such younger realists as Myres $\mathrm{McDougal}$ or Fred Rodell. Brief biographical material on most of the realists is available in Association of American Law Schools, Directory of Teachers in Member Schools (St. Paul, Minn., r922-4I).

10 Benjamin N. Cardozo, "Jurisprudence," in Selected Writings of Benjamin Nathan Cardozo, ed. Margaret E. Hall (New York, I947), 8.

11 "Address of Elihu Root in Presenting the Report of the Committee," American Law Institute, Proceedings, I (Pt. 2, 1923), 48, cited in Rumble, American Legal Realism, I56. On the growth of case law, see also Benjamin N. Cardozo, The Growth of the Law (New Haven, Conn., I924), 1, 3-5, 16.

12 Grant Gilmore, "Legal Realism: Its Cause and Cure," Yale Law Journal, LXX (June 1961), 1040-4I. 
great chagrin and bewilderment, members of the legal profession began uncovering contradictory and conflicting decisions with ever-increasing frequency.

That plight was so widely recognized that in 1923 Root and a number of his orthodox colleagues helped establish the American Law Institute to abolish confusion by a clear and updated "restatement" of the law. The organization's first report emphasized, in addition to the flood of precedents, a number of other contributing causes of legal uncertainty, including a lack of precision in the use of legal terms and a lack of agreement on basic common-law principles. ${ }^{13}$ For many of the young critics the widely acknowledged confusion was clear evidence that the syllogistic certainty of the law was a hollow claim and that the actual role of the individual judge was much wider and more crucial than the older jurisprudence allowed.

The very fact that the new American Law Institute was attempting a "restatement" of the law was an additional factor provoking the new critique. Such a "restatement" assumed that law pre-existed in some whole form that could be discovered by logical analysis and that the job of the American Law Institute was merely to write it down. Most of the members of the institute still believed in the validity of the older juristic method and thought that a more rigorous application would resolve all difficulties. Convinced that law was a human product related to changing social and cultural conditions, the new critics rejected the idea of an official "restatement" as an impossible goal. ${ }^{14}$

The practical experience of many of the realists served to strengthen their awareness of the changing and subjective elements in the legal system. The great majority of them had practiced law for at least a year before starting to teach, and they were aware of the many individual, human factors that lay behind the actions of lawyers and judges. They knew firsthand the conflicting and confused nature of many precedents and rules. Such practical experience, as well as their pragmatic outlook, helped lead many of them to hostility toward the older jurisprudence. Recognizing the need both to understand the actual relationship between law and a changing society and to explain the reasons behind contemporary practice, they began their concerted though diverse probing for a new and scientific jurisprudence.

By the end of the twenties Yale, Columbia, and Johns Hopkins Universities had become the centers of the new legal criticism. Charles E. Clark, who succeeded Robert M. Hutchins as dean of the Yale University Law School in r929, brought such aggressive scholars as Jerome Frank, Walter Nelles, William O. Douglas, Thurman Arnold, and Robinson to New Haven. In cooperation with Johns Hopkins University three of the most scientific-minded critics, Walter

\footnotetext{
13 Committee on the Establishment of a Permanent Organization for the Improvement of the Law, "The Law's Uncertainty and Complexity," American Law Institute, Proceedings, I (Pt. I, I923), 66-76.

14 For a brief bibliography of the realist critique of the program of the American Law Institute, see Rumble, American Legal Realism, 156, n. 40.
} 
Wheeler Cook, Herman Oliphant, and Hessel E. Yntema, founded the researchoriented Institute of Law in 1929. At Columbia University Karl N. Llewellyn, often regarded as the most important of the new critics, joined with Edwin W. Patterson, Underhill Moore, and others in publishing sharp essays probing the weaknesses of traditional jurisprudence. Dean Leon Green of Northwestern University, Felix S. Cohen of the New School for Social Research, Max Radin of the University of California, Thomas Reed Powell of Harvard University, and Judge Joseph C. Hutcheson of the United States District Court in Texas were among those whose work placed them in the forefront of the new movement.

The intense debate over legal realism as a collective movement began in $193^{\circ}$ when Llewellyn and Frank, then an attorney practicing in New York, published separate essays that struck the legal profession in rapid succession. Llewellyn used the phrase "Realistic Jurisprudence" to describe his suggested approach, and soon the term "legal realism" came to stand for the general attitude of all the new critics. While most of the so-called realists disliked the label, their enemies seized upon it as an epithet to brand what they considered an unsound and often dangerous attitude.

Llewellyn's article on "Realistic Jurisprudence" centered on the distinction between abstract legal verbalisms and concrete empirical facts. "The traditional approach is in terms of words; it centers on words," he explained, adding pointedly, "it has the utmost difficulty in getting beyond words." 15 Legal phrases and concepts were simple devices to make the world more manageable, but the history of American law showed that those necessary abstractions "tend to take on an appearance of solidarity, reality and inherent value which has no foundation in experience." ${ }^{\text {"6 }}$ Hence they led to a rigidity that forced new facts and situations to conform to outmoded concepts or else ignored the new altogether. Much of the law was an exercise in painful definition and strained syllogism that bore little resemblance to the real world it was supposed to govern.

Such an important concept as that of the legal rule was a perfect example of the danger and ambiguity inherent in rigid abstractions, Llewellyn declared. While such authoritative rules were supposed to lead judges to proper decisions, they were in fact so vague and confused as often to be no help at all. When lawyers talked of legal rules, no one knew whether they were the lawyer's rule or the court's; whether they represented what the courts should do, or what they had done in fact; whether courts actually followed them, or merely used them to justify a decision reached on other grounds. Such fuzzy conceptions of legal rules led to large-scale uncertainty and contradiction in actual decisions and caused massive and often absurd twisting of terms in legal argumentation. Fundamental

\footnotetext{
${ }^{15}$ Karl N. Llewellyn, "A Realistic Jurisprudence--The Next Step," Columbia Law Review, XXX (Apr. 1930), 443.

16 Ibid., 453.
} 
conceptual imprecision, Llewellyn concluded, could only mean "confusion, profuse and inevitable."17

He insisted that there was almost always a gap between the so-called rules of a case and its practical settlement. Admitting that legal rules had some uncertain influence on judges, he resolutely maintained that a realistic study of the law demanded an examination of the extent to which the rules actually controlled or influenced the case. "You cannot generalize on this, without investigation," Llewellyn insisted. If men were ever to understand the legal system, they would have to study individual cases empirically. "The significance of the particular rule," he stressed, "will appear only after the investigation of the vital, focal phenomenon: the behavior." 18

Llewellyn's empirical approach concentrated on behavior as the proper subject of study for the legal scholar. Behavior was real, whereas most legal argumentation was simply verbal game playing. Following Holmes's lead, Llewellyn defined law in terms of the coercive actions taken by government officials. Regardless of syllogisms and definitions, the actual law was what the public force would support. "What these officials do about disputes," Llewellyn wrote in a sentence that returned to haunt him, "is, to my mind, the law itself." 19 Using such a definition, the whole legal process was clearly susceptible to empirical study. Again following Holmes, Llewellyn declared that concepts of justice and ethical right had to be ignored when the actual operations of the law were analyzed. Such concepts merely confused the investigator by mixing considerations of "ought" where only the realities of "is" were relevant. "The most fruitful thinking about law," he remarked, "has run steadily toward regarding law as an engine (a heterogeneous multitude of engines) having purposes, not values in itself."

Accepting most of Llewellyn's ideas, Frank went far beyond them in earning his reputation as one of the most extreme realists. Whereas Llewellyn believed that rules and precedents were relevant and of some importance, Frank did not even consider them a meaningful part of the law. To him law meant a particular judicial determination upon a particular and singular set of facts. Reducing law to what he considered an unequivocal empirical minimum, Frank equated it solely with the specific individual judicial decisions. "Until a court has passed on these facts," he insisted, "no law on that subject is yet in existence." 1

Rules and precedents were not part of the law because they had little if any effect on actual judicial decisions. No one could reason out a decision by syllogism, Frank declared. Instead judges had "hunches" about how cases should be decided and then looked up the proper rules that would support their "hunch." "Judicial judgments, like other judgments," Frank maintained, "doubtless in most cases,

17 Ibid., 439.

18 lbid., 444 .

19 Karl N. Llewellyn, The Bramble Bush (New York, 1930), 12.

20 Id., "Realistic Jurisprudence," 464.

21 Jerome Frank, Law and the Modern Mind (2d ed., New York, 1963), 50. 
are worked out backward from conclusions tentatively formulated."22 A judicial opinion was actually only the judge's rationalization, not the real explanation for his decision. Judges manipulated precedents in the same way: after they made their decision, they sought favorable precedents or reinterpreted unfavorable ones to support it. "What the courts in fact do," Frank charged, "is to manipulate the language of former decisions." ${ }^{23}$

As a result of realistic, empirical analysis of actual decisions, it became clear that the law was not a rational whole, nor even largely logical. In addition to personal prejudices, judicial objectivity was further deflected by the necessity of relying on secondhand evidence concerning the facts, relayed by lawyers, parties to the case, and witnesses who distorted the facts through prejudice, misunderstanding, ignorance, or simple falsification. The facts of any case were thus necessarily elusive and essentially subjective. The law was vague, uncertain, and necessarily partial and prejudiced. "To predict the decisions of the courts on many a point," Frank argued, "is impossible." ${ }^{24}$

In spite of the practical uncertainty and subjectivity, Frank continued, most lawyers and judges still insisted that law was essentially rational and certain. The explanation for that contradiction, he suggested, lay in what he called the "legal absolutist" mind. The father-child pattern, bred deeply during every individual's childhood, drove most men continually to seek some powerful authority figure which would act as a substitute for the "Father-as-Infallible-Judge." ${ }^{25}$ Because the law served as a natural authority figure, Frank concluded, it subconsciously stimulated the latent childish emotions of those who studied it. "We would seem to be justified in surmising that the subject-matter of the law is one which evokes, almost irresistibly, regressive emotions." ${ }^{26}$ Most lawyers and judges, therefore, unconsciously developed an "absolutist" viewpoint that made them see the law as a father-like authority figure, necessarily certain and just in operation. That subconscious drive prevented them from recognizing the true nature of the legal system.

The manipulation of abstract concepts provided the method with which lawyers and judges could construct a façade of certainty and absolute rationality over the confused legal process. Referring to such manipulation as "Platonism" and "Scholasticism," he charged that the "absolutists" used "magical phrases" to convince themselves that all was well and to rationalize awkward facts. Frank considered concrete facts as the only important reality. Such abstract rationalizations were merely escapes and delusions. "Virtually empty concepts," Frank remarked, "seem to give to the metaphysician the stable world he requires."27

22 Ibid., 109; see also ibid., I I4-21.

23 Ibid., I 59.

24 Ibid., 6.

25 Ibid., 19.

26 lbid., 98 .

27 lbid., 65 . 
Because the concepts were empirically empty-they did not bear a definite and constant relation to any concrete reality-they were liable to all kinds of twisting and reinterpreting. In such a way lawyers were able to reconcile completely contradictory judicial decisions as "logical" under the same principle or precedent.

Although he declared that the great majority of men believed in the certainty of law, Frank was primarily interested in, and hostile toward, traditional legal theories and their contemporary advocates who controlled the bench and the bar. Using a technique reminiscent of that of Veblen, Frank on several occasions remarked in footnotes or appendixes that his psychoanalytic approach provided only a partial explanation for the legal quest for certainty. But after making that qualification in obscure places, usually he continued in the text to write as if that approach were the only explanation. Indeed, while consistently proclaiming lawyers and judges highly intelligent and learned men, he described them throughout as immature, childish, and irrational.

The two works by Frank and Llewellyn had an immediate impact. Pound, then dean of the Harvard Law School and the most renowned legal scholar in America, responded early in 1931, ironically in an issue of the Harvard Law Review dedicated to Justice Holmes on his ninetieth birthday. Although Pound had earlier espoused many of the attitudes associated with realism, by I93I he had become wary of some of the more radical implications of pragmatism and positivism in the law. He was perhaps, in addition, moved to reply by the fact that both Llewellyn and Frank had specifically attacked his work on juristic theory. Undoubtedly having Frank most clearly in mind, Pound accused an unnamed group of "realists" of allowing their naive faith in empiricism to lead them into a philosophical nominalism that denied the existence of legal rules, doctrines, principles, and concepts. They overemphasized irregularities and contradictions and ignored the uniformity and reasonableness of the law. By focusing on subjective motives and behavior of judges, Pound asserted, the realists were leading legal science into a dead end. ${ }^{28}$

Considering his attack unfair, Llewellyn and Frank replied jointly and claimed that Pound's criticisms were almost wholly unwarranted. The importance of the reply was that Llewellyn and Frank gathered together and defended twenty of the better-known critics who, they explained, could be taken as a fair sample of the new approach to the law. While emphasizing that the twenty represented no "school" and were by no means in complete agreement in their own attitudes, Frank and Llewellyn admitted that their criticisms of existing legal theory gave them a unified approach. By the end of I93I the new critics had been attacked and defended, and, most importantly, they had been personally identified and categorized. ${ }^{2 \theta}$

\footnotetext{
${ }^{28}$ Roscoe Pound, "The Call for a Realist Jurisprudence," Harvard Law Review, XLIV (Mar. I93I), 697-7II.

${ }^{29}$ Llewellyn, "Some Realism about Realism," 1222-64. Although Llewellyn alone signed the
} 
While Frank alone had attempted a sweeping psychoanalytic interpretation, he and Llewellyn had agreed on several key points. They assumed that human knowledge could never be certain and uniformly logical and that law was a constantly changing phenomenon. They denounced abstract verbal formulas and absolutes as the bane of clear thinking, legal or otherwise. They agreed that the "is" and the "ought" should be temporarily separated for the purpose of precise study. Finally Llewellyn and Frank were united in calling for careful empirical studies of the way the law actually operated in society, with an emphasis on the dubious practical impact of legal rules and the likelihood that judicial opinions were at least partly rationalizations. Because of that focus on judicial motivation, both of them, like most realists, looked to their colleagues in psychology for clues to help explain the legal process. Behaviorism, Freudianism, and abnormal psychology all played a role in the new movement. ${ }^{30}$ Around those basic attitudes the realists centered their attacks on traditional jurisprudence.

Although the young critics were firm believers in democracy, most of them embraced an empirical relativism that raised both practical and theoretical questions about the nature of democratic government. The most important practical point of their argument was to question and in many cases to reject the idea of a government of laws rather than of men. While most democratic legal theoriesand the United States Constitution-held that established and known laws alone should be binding on free citizens, the realists maintained that such laws were nonexistent and impossible to attain. Frank had argued that law was uncertain in administration and depended largely on the subjective motivations of the particular judge who heard the case. "It is fantastic, then," he had declared, "to say that usually men can warrantably act in reliance upon "established law. ",31

Frank based much of his analysis of the judicial process on the work of Judge Hutcheson, who claimed that all judges reached their decisions by "hunches" based on an "intuitive flash of understanding" that revealed the proper decision in a case. He was referring, Hutcheson pointed out, not to the rationalization or the "logomachy" that the judge used to explain his opinion, but to the actual way in which he decided a case. "The vital, motivating impulse for the decision," he remarked, "is an intuitive sense of what is right or wrong for that case."32 If that were the process of decision, then the social, economic, and moral values of the judge were far more important than the rest of the legal structure, and the law was clearly a subjective, changeable phenomenon.

Most of the new critics accepted an analysis similar to Hutcheson's and tried to base their legal theory on a subjective conception of judicial decisions.

article, he explained that it had been conceived and researched in cooperation with Frank. Because Llewellyn did the actual writing, Frank did not think he should receive credit as an author.

30 Patterson, Jurisprudence, 548-52.

31 Frank, Law and the Modern Mind, 125.

32 Joseph C. Hutcheson, Jr., "The Judgment Intuitive: The Function of the 'Hunch' in Judicial Decision," Cornell Law Quarterly, XIV (Apr. 1929), 285. 
Radin emphasized the number of conflicting rules that pertained to any case. In such a situation the judge was forced to decide cases on an expectation of their probable social results. Since that meant a reliance on the judge's subjective value standards, the process was actually a matter of personal motivation. "Judges, we know, are people," Radin commented, and they thus make their decisions like all other people. ${ }^{33}$ Yntema made the point even more explicitly: "The ideal of a government of laws and not of men," he maintained, "is a dream." ${ }^{34}$ The subjective motives of the judge, not the existence of rules, or even constitutions, provided the key to understanding the law.

Morris R. Cohen, a philosopher at the City College of New York and a leading critic of realism, pointed to the antidemocratic implication of such a judicial theory. "To be ruled by a judge," Cohen declared, "is, to the extent that he is not bound by law, tyranny or despotism."35 When the realists claimed that the judge's subjective decision was the only law, he implied, they were justifying judicial despotism.

At that point, the theoretical force of the realist critique became clear, for it rejected any concept of a higher law that could provide judges with objective, rational guidance to assure a just operative law. A pervasive scientific relativism that seemed to undermine any objective or absolute moral standard underlay the realist approach. Llewellyn and Frank had both assailed abstract logic and deductive rationalism and scorned the absolutes that those approaches generated. Their determination to make concrete empirical facts the touchstone for all analytical concepts seemed necessarily to exclude ideas of "ought" in favor of facts about "is." If what men ought to do was not identical with what they did in fact, then there was no basis in their approach for discussing moral concepts except as mere psychological data. It would, in any case, be impossible to establish the objective validity of any such ethical values.

Some of the realists made their relativism explicit and direct. Cook, another of the founders of the Institute of Law at Johns Hopkins University who had been trained first as a physicist, looked enthusiastically to the physical sciences for his legal inspiration. Scorning the futility of deduction, he emphasized that human knowledge had "reached the era of relativity." By relativity, he explained, he meant "a point of view, which, whatever may happen to specific doctrines, seems destined to remain as a permanent achievement in human thought." ${ }^{36}$ Neither legal nor moral theory could escape that era.

Applying the scientific, relativist approach to the question of legal and moral

\footnotetext{
${ }^{33}$ Max Radin, "The Theory of Judicial Decision: Or How Judges Think," American Bar Association Journal, XI (June 1925), 359.

84 Hessel E. Yntema, "The Hornbook Method and the Conflict of Laws," Yale Law Journal, XXXVII (Feb. 1928), 476 .

35 Morris R. Cohen, "Positivism and the Limits of Idealism in the Law," Columbia Law Review, XXVII (Mar. 1927), 244.

${ }^{86}$ Walter Wheeler Cook, "Scientific Method and the Law," American Bar Association Journal, XIII (June I927), 305.
} 
standards, Moore, who taught first at Columbia University and later at Yale, similarly rejected the idea of absolutes: "Ultimates are phantoms drifting upon the stream of day dreams." Arguing for a pragmatic standard of judgment, he insisted that "human experience discloses no ultimates."37 Nelles, a professor at Yale University, carried the approach to its extreme. "I deny ethical right and ought without qualification," he declared in 1933. He scorned the possibility of both scientific and deductive ethics. "In the twentieth century," he remarked, "popular feeling of the wickedness of denying ethical right and ought can no longer command the unconscious deference of an important mind." minds of most of the realists there could be no such thing as a demonstrable moral standard.

The pragmatism and apparent ethical relativism of men like Cook, Moore, and Nelles shocked much of the legal profession. Although the counterattack did not reach its bitterest phase until after 1935, it had clearly begun by the early thirties. John Dickinson, one of Pound's leading disciples, and Hermann Kantorowicz, a professor at the New School for Social Research, criticized the realists for dismissing the importance of rules and pointed to the philosophical difficulties in their approach. ${ }^{39}$ Hutchins, then president of the University of Chicago, and Mortimer Adler, a prominent philosopher, joined the assault on realism, basing their attacks on an Aristotelian-Thomistic philosophy. Rationally knowable moral principles, not inchoate empirical facts, were the proper foundation of jurisprudence. ${ }^{40}$ By excluding ethical considerations and reverting to a philosophical nominalism, many scholars believed, the realists were necessarily making force the only meaningful arbiter of human affairs and destroying the ethical basis of democracy.

To harm the cause of democratic government was the last thing the realists hoped to do. In attacking traditional abstractions and nonempirical concepts of justice, they were usually assailing what they considered the practical injustices of American society. Abstraction in economics and politics, as in the law, they believed, had been one of the biggest obstacles to the attainment of a truly democratic society. Frank, Oliphant, Clark, Arnold, Douglas, and Felix Cohen were all ardent New Dealers who shared a strong hostility to the method of juristic reasoning that struck down social welfare laws and wrought what they considered great human injustices. Most of the other realists expressed equally strong disapproval of the social and economic situation of the thirties. The new

37 Underhill Moore, "Rational Basis of Legal Institutions," Columbia Law Review, XXIII (Nov. 1923), 612 .

${ }_{38}$ Review of Cohen, Ethical Systems and Legal Ideals, ibid., XXXIII (Apr. I933), 767, 766.

39 John Dickinson, "Legal Rules: Their Function in the Process of Decision," University of Pennsylvania Law Review and American Law Register, LXXIX (May 1931), 833-68; Hermann Kantorowicz, "Some Rationalism about Realism," Yale Law Journal, XLIII (June 1934), 1240-53.

${ }^{40}$ Hutchins' most famous attack on legal realism appeared as "The Autobiography of an Ex-Law Student," reprinted in No Friendly Voice (Chicago, 1936), 41-50; Mortimer Adler, "Legal Certainty," Pt. 2 of "Law and the Modern Mind: A Symposium," Columbia Law Review, XXXI (Jan. I931), 82-115. 
criticism was thus not intentionally hostile toward the idea of democratic government. Indeed, after 1932 it lent itself readily to the support of concrete political reform. As early as 193r Frank defended the realists against charges that they excluded ethical considerations from the law. "The point is," he retorted, "that the rational and ethical factors are thwarted in their operations by the conventional tendency to ignore the non-rational and non-ethical factors." ${ }^{11}$ The problem was not whether there was something abstract called justice, but rather how human relations could be made more just in practice. Though the theoretical problems the realists raised left them open to bitter attack, the obtuse formalism of American constitutional interpretation throughout the first third of the twentieth century helped drive them to their extreme positions. The manifest human needs created by the depression further convinced them of the need for a more realistic and flexible legal theory to attain what they considered a truly democratic society.

While the early critiques of legal realism tended to be mild and often discriminating, by 1936 they were becoming wholly denunciatory. The tone of the attack grew in bitterness in proportion to the spread of fear and uncertainty created by the success of the totalitarian governments of Europe. As Americans became more acutely aware of the despotic and repressive practices in Russia, in Italy, and most especially in Germany, the great majority condemned them in clear and forceful terms. As the possibility of another war drew nearer, they clung more tightly to the ideal of democracy as the best and morally ideal form of government. The realists had raised, unintentionally, fundamental questions about the possibility and validity of democratic government at a time when the country needed reassurance and conviction.

Inside the ominous framework constructed by the existence of the totalitarian governments, a new extremism in the realist movement itself was working to invite the bitter attack. In 1935 Robinson and Arnold, who jointly conducted seminars at the Yale University Law School on psychology and the law, published studies that assumed a sweeping ethical relativism. Robinson, who revealed a marked antipathy toward traditional deductive juristic thought, argued that the whole legal system should be reformed in line with the discoveries of modern scientific psychology. Committed to a thoroughgoing empiricism, he charged that "there is not now and never has been a deductive science of ethics." ${ }^{2}$ Moral values developed, instead, out of concrete situations and were intelligible only in that context. No absolute, abstract, or universal moral values existed.

Arnold went beyond Robinson's position and argued that abstract theories and moral values were not only unfounded, but were wholly mythical. Moral ideals served only as satisfying symbols for emotional needs and had no further

\footnotetext{
41 Review of Llewellyn, Bramble Bush, Yale Law Journal, XL (May 1931), II2I n. For an example of the relationship between legal realism and political reform, see Jerome Frank, "Modern Trends in Jurisprudence," American Law School Review, VII (Apr. 1934), 1063-69.

42 Robinson, Law and the Lawyers, 225; see also review of Harold Ernest Burtt, Legal Psychology, Yale Law Journal, XLI (May 1932), 1106.
} 
connection with anything real. The proper way to study theories and ideals, Arnold explained, was to ignore them as "principles of truth" and regard them simply "as symbolic thinking and conduct which condition the behavior of men in groups." ${ }^{33}$ In fact, he concluded, if theories were to be effective as emotional symbols, they would have to be empirically false. In his sweeping rejection of the validity of such ideals Arnold left no basis for distinguishing between morally good or bad symbols or for establishing the legitimacy of any ethical position whatever. In his approach ethical values faded through relativism and out of existence.

Shortly after their two books were published, at a time when men could see the rampant brutality of Nazism, the vigorous counterattack began its harshest phase. Rufus C. Harris, dean of the Tulane University Law School, Philip Mecham, a professor at the University of Iowa Law School, and Morris R. Cohen all charged that realism paved the way for totalitarianism by denying objective ethical standards and making law an amoral coercive force. ${ }^{44}$ Edgar Bodenheimer, an attorney in the Solicitor's Office in the Department of Labor, argued the same line in his important work on jurisprudence. "There is a certain danger that the skepticism of realistic jurisprudence may, perhaps very much against the intents and wishes of its representatives, prepare the intellectual ground for a tendency toward totalitarianism." 45

The growing condemnation of realism reached a climax in 1940 when two of the most prominent legal scholars in the country, Pound and Lon L. Fuller of Duke University, published lectures assailing the new movement. Pound had long been critical of realism, and by 1940 he was ready to name it a "giveit-up philosophy." Refusing to discuss the work of any particular individual, he issued a blanket charge against them all: "The political and juristic preaching of today leads logically to [political] absolutism." ${ }^{\text {(6 }}$ Fuller, like Pound, had earlier shared some of the attitudes associated with realism, but by 1934 he had turned into a stalwart critic. Realism attempted the impossible, he argued, for man could never ignore the ethical problems in the law, not even for the alleged purpose of scientific scholarship. In the end realism "remains formal and sterile." Such a negative attitude spreading through society was a major cause, he explained, "in bringing Germany and Spain to the disasters which engulfed those countries."

43 Thurman Arnold, The Symbols of Government (2d ed., New York, 1962), xiv; see also ibid., 10, $17,34,98$.

44 Rufus C. Harris, "Idealism Emergent in Jurisprudence," Tulane Law Review, X (Feb. 1936), 169-87; Philip Mecham, "The Jurisprudence of Despair," lowa Law Review, XXI (May 1936), 669-92; review of Robinson, Law and the Lawyers, Cornell Law Quarterly, XXII (Dec. 1936), 171-78; and review of Arnold, Symbols of Government, Illinois Law Revicw, XXXI (Nov. 1936), $4 \mathrm{II}-\mathrm{I} 8$.

45 Edgar Bodenheimer, Jurisprudence (New York, 1940), 316.

46 Roscoe Pound, Contemporary Juristic Theory (Claremont, Calif., 1940), 9; see also ibid., I, 8-II.

${ }^{47}$ Lon L. Fuller, The Law in Quest of Itself (2d ed., Boston, 1966), 89, 122; see also ibid., $4-6$, II, $64-65$. 
Though Pound and Fuller attacked realism vigorously, the most severe and extreme attacks came from a number of Catholic legal scholars who during the thirties helped to generate a resurgent Neo-Scholastic legal movement in the United States. Much of the impetus came from the work of the American Catholic Philosophical Association, which established a round table on philosophy and law at its meeting in 1933. In addition to sponsoring scholarly papers and monographs, the round table attempted to organize a unified jurisprudence among professors at all Christian church-related law schools in the country. Although relatively few non-Catholics expressed interest, the suggestion drew support from many Catholics who saw the situation as desperate.

As other critics had done, the Catholics pictured realism as ethical relativism undermining the foundations of democracy. Those who adhered to such doctrines as pragmatism and empiricism, as the realists did, declared Dean Clarence Manion of the Notre Dame University Law School, were betraying the American citizen and "preparing to sell him into slavery." ${ }^{38}$ Such dire predictions exceeded those of most other critics, for many of the Catholics refused to qualify them in any way. They saw such a definite and direct causal connection between ethical relativism and totalitarianism that they seemed to believe in what has been called the autonomy of ideas. Disregarding such factors as economic structures and political institutions, they argued that the ideas associated with legal realism and ethical relativism, by themselves, would lead naturally and inevitably away from traditional democracy to a ruthless totalitarianism. "Godless Behaviorism and Pragmatism are the headhunters, with Democracy and popular sovereignty the victims," declared Father Francis E. Lucey, a regent of the Georgetown University School of Law. "Democracy versus the Absolute State means Natural Law versus Realism." 49

While the reaction against pragmatism and relativism was bitterest in the legal profession, the attack spread through all areas of American intellectual life. In the fields of history, philosophy, literature, and the social sciences many scholars began pointing to the dangerous implications of scientific relativism and condemning their colleagues who had embraced some form of it. By 1937 Walter Lippmann had completely rejected his earlier pragmatism and condemned the "aimless and turbulent moral relativity" of twentieth-century social thought. ${ }^{\mathbf{5 0}}$ Hans Kohn, Lewis Mumford, Reinhold Niebuhr, Thomas Mann, Alvin Johnson,

${ }^{48}$ Clarence Manion, "The American Metaphysics in Law," Proceedings of the American Catholic Philosophical Association, XVIII (1942), 133-34. For examples of the Catholic critique, see Miriam Theresa Rooney, "Law and the New Logic," ibid., XVI (1940), 192-222; Brendan F. Brown, "Natural Law and the Law-Making Function in American Jurisprudence," Notre Dame Lawyer, XV (Nov. 1939), 9-25; Frederick J. deSloovere, "Natural Law and Current Sociological Jurisprudence," Proceedings of the American Catholic Philosophical Association, XVII (194I), 137-42; Dietrich von Hildebrand, "The Dethronement of Truth," ibid., XVIII (1942), 3-16; and Paul L. Gregg, "The Pragmatism of Mr. Justice Holmes," Georgetown Law lournal, XXXI (Mar. 1943), 262-95.

49 Francis E. Lucey, "Natural Law and American Legal Realism: Their Respective Contributions to a Theory of Law in a Democratic Society," ibid., XXX (Apr. 1942), 526, 533 .

50 Walter Lippmann, An Inquiry into the Principles of the Good Society (Boston, 1937), 380. 
and Van Wyck Brooks were among those who joined in blaming pragmatists and relativists for the desperate state of world affairs. "This recognition of guilt must pave the way, not to maudlin regrets," they declared in a united manifesto, "but to immediate atonement."

Although the critics of legal realism undoubtedly believed that the new attitude directly threatened the existence of democracy, many of them were animated also by other social motives. Some critics, for example, were representatives of the wealthy groups that had violently opposed the New Deal since 1934 and correctly understood the devastating relevance of realism to their strained method of constitutional interpretation. One of the most extreme attacks, for example, came from a New York lawyer, Raoul E. Desvernine, who had been in charge of the Legal Division of the American Liberty League. When he charged in 194I that realism was "radically subversive of the American way of life," few could have doubted that he had specifically in mind the realist argument for a more permissive constitutional attitude toward New Deal legislation. ${ }^{52}$ For those who already regarded the New Deal as protototalitarian there was no real distinction between attacking the Roosevelt administration and condemning legal realism as antidemocratic. Rather, the accepted fact of New Deal regimentation gave evidence to the charge against the legal attitude that defended and justified such regimentation.

There was a different ulterior motive behind the attacks of most of the Catholics, who politically were generally sympathetic to the New Deal. The intellectual attitudes they associated with legal realism denied their deepest articles of religious faith and emotional conviction. The Catholic faith in its fundamentals was indissolubly linked with a hierarchical institution that claimed ability to interpret an absolutely true moral law, based on the truths of revelation and reason. Realism and modern empiricism rejected those foundations, and the Catholics began their assault in defense, not just of their conception of democracy, but of their faith and their Church. Because of their religious and philosophical conviction that such attitudes were false and evil, they quickly identified them with the practice of totalitarianism, which was also false and evil. A number went so far as to identify American democratic ideas with their own Catholic philosophy. The "definite American philosophy of life," explained one typical writer, was "drawn directly from the Catholic philosophy of life." ${ }^{53}$ Having long been considered not completely American, the Catholics were at last able to assert their legitimacy by defining themselves as the true descendants of the American Revolution, and at the same time discrediting their dangerous intellectual adversaries. ${ }^{54}$

51 Hans Kohn et al., The City of Man: A Declaration on World Democracy (New York, 1940), 19. 52 Raoul E. Desvernine, "Philosophy and Order in Law," Proceedings of the American Catholic Philosophical Association, XVII (I94I), I35-36.

${ }_{53}$ William Franklin Sands, "What Is an American?" Commonweal, XXXIII (Feb. 21, 1941), 438.

${ }^{54}$ See also Moorehouse F. X. Millar, "The Origins of Sound Democratic Principles in Catholic 
Whatever their motivations, the attacks had an effect. Much of the work of the realists had slighted the importance of ethical theory. Their philosophical assumptions had undermined the concept of a rational moral standard. Their ethical relativism seemed to many to mean that no Nazi barbarity could be justly branded as evil, while their identification of law with the actions of government officials gave even the most offensive Nazi edict the sanction of true law. Juxtaposing that logic to the actions of the totalitarian states, the critics had painted realism in the most ominous and shocking colors.

The damning charges forced the realists to assert their innocence. "I hope," declared Radin, "I have never said that ideas like wrong and right, or any ideas, are worthless or meaningless terms." ${ }^{\text {"55 }}$ An empiricism that tried to predict actual decisions was "an incomplete way to see law," Llewellyn admitted in 1940, for "the heart and core of Jurisprudence" was the problem of ethical purpose in the law. "I for one," Llewellyn exclaimed, "am ready to do open penance for any part I may have played in giving occasion for the feeling that modern jurisprudes or any of them had ever lost sight of this." ${ }^{\text {"6 }}$ Frank, Yntema, Patterson, and Felix Cohen all explicitly defended the realists against their critics, arguing that they had never denied an ethical goal in the law. ${ }^{57}$ That defense was only partially relevant, however, since the fundamental question was actually whether the basic philosophical and methodological assumptions that characterized realism left any rational basis for affirming the legitimacy of an ethical goal.

Facing a barrage of criticism for his extreme views, Frank ultimately drew closer to the natural law school than any of the other realists. During the early forties he looked increasingly for the moral justification of democracy and seemed to find it in the Thomistic concept of natural law. By 1945 he was maintaining that most Americans refused to accept the concept of natural law only because of a confusion in terminology that gave them the wrong idea of its true meaning. "Most intelligent Americans, if the 'basic principles' of Scholastic natural law are described to them," he argued, "will find them completely acceptable." ${ }^{\text {" Th }}$ Three

Tradition," Catholic Historical Review, XIV (Apr. 1928), 104-26, and "Scholastic Philosophy and American Political Theory," Thought, I (June I936), I I2-36; Raoul E. Desvernine, "The Creed of Americanism," Notre Dame Lawyer, XVII (Mar. 1942), 216-26; Robert I. Gannon, "What Are We Really Fighting?" Fordham Law Review, XI (Nov. 1942), 249-54; Goetz Briefs, "Philosophy of the Democratic State," Proceedings of the American Catholic Philosophical Association, XV (1939), 36-50; and Patrick J. Roche, Democracy in the Light of Four Current Educational Philosophies (Washington, D. C., I 942 ).

${ }^{55}$ Max Radin, "In Defense of an Unsystematic Science of Law," Yale Law Journal, LI (June I942), I 275 .

${ }_{56}$ Karl N. Llewellyn, "On Reading and Using the Newer Jurisprudence," Columbia Law Review, XL (Apr. 1940), 593,603.

${ }^{57}$ Hessel E. Yntema, "Jurisprudence on Parade," Michigan Law Review, XXXIX (May 194I), I164-65; Edwin W. Patterson, "Forward," in Edwin N. Garlan, Legal Realism and Justice (New York, 194I), viii; Felix S. Cohen, "The Problems of a Functional Jurisprudence," Modern Law Review, I (June 1937), 24-25; Jerome Frank, If Men Were Angels: Some Aspects of Government in a Democracy (New York, 1942), Appendix v, esp. 297-300.

58 Jerome Frank, Fate and Freedom: A Philosophy for Free Americans (New York, 1945), 295; see also ibid., 98-99, 259-6o. 
years later he made his position clear and unequivocal: "I do not understand how any decent men today can refuse to adopt, as the basis of modern civilization, the fundamental principles of Natural Law, relative to human conduct, as stated by Thomas Aquinas." 59 Although Frank still called for empirical analysis of the legal system and insisted on the uncertainty and confusion in the application of principles, he had come a long way from the philosophical implications of Law and the Modern Mind.

Llewellyn, too, moved in the direction of natural law, though he stopped short of Frank's enthusiastic acceptance. Although he acknowledged a recent "debt" to Aquinas for the Schoolman's work on the philosophy of law, Llewellyn embraced neither Thomism nor the whole doctrine of natural law. ${ }^{60} \mathrm{He}$ accepted instead the general idea of a natural law, but translated it into a less precise and more intuitive concept. Natural law, he believed, was the name given for a universal human "urge" or "drive" for "right, or decency, or justice." Rather than being the opposite of legal empiricism as many had charged, Llewellyn declared, natural law was "an interesting and highly useful complement." ${ }^{1}$

While Llewellyn added a general concept of natural law to his legal theory and emphasized the importance of proper ethical ends in law, he remained true to his empiricism and retained a sharp skepticism concerning the powers of deductive logic. "When it comes to ultimate substance of the Good," he wrote early in 1942, "I repeat that I can find no clarity, or any conviction of reason, or of deduction as to specific matters, from the broad ultimates others have found clear." If pressed for an ultimate justification for democratic government, or for any values, he admitted, "I have no answer."

In spite of their early leadership, neither Llewellyn nor Frank was typical of the other realists in the move toward natural law. Radin perhaps best represented the others. Acknowledging that realism must place an added weight on ethical considerations, he declared that "the lawyer's task is ultimately concerned with justice" and emphasized that "any legal teaching that ignored justice had missed most of its point." ${ }^{\prime 3}$ But even with the modification in his outlook, Radin remained a convinced empiricist with no use for abstract formulations. Justice or any other idea, he declared in I940, "has no objective existence." Hence it existed only in the minds of men and was, therefore, only meaningful to the extent that actual men subscribed to it. In that case the concept of justice held by juridical officials was the source of a community's operative concept of justice. "In the last analysis," Radin argued, "justice must be a common denominator of what a specific group-the judges themselves-think is just." "O4 "Objectified"

59 Id., "Preface to Sixth Printing," Law and the Modern Mind, xx.

${ }^{6} \mathrm{Karl}$ N. Llewellyn, "On the Good, the True, the Beautiful, in Law," University of Chicago Law Review, IX (Feb. 1942), 247.

61 Id., "One Realist's View of Natural Law for Judges," Notre Dame Lawyer, XV (Nov. 1939), 3, 8.

62 Id., "On the Good, the True, the Beautiful, in Law," 264.

63 Max Radin, "The Education of a Lawyer," California Law Review, XXV (Sept. 1937), 688.

-4 Id., Law as Logic and Experience (New Haven, Conn., 1940), I56-58. 
justice was real, fundamental, and essential, but it was necessarily a changing justice, wholly relative to the moral beliefs of the community in general and of the judges in particular.

Thus, while the realists modified their tone and protested their innocence, they did not, with the exception of Frank, give in to their critics on any fundamental point. They agreed that deduction was sterile in the field of values and claimed that their critics were as unable as they were to demonstrate conclusively the ultimate validity of any ethical ideals. Most would have agreed with Cook, who compared the advocates of deductive ethical systems to the infants in John Watson's experiments who exhibited "fear reaction" when they lost their sense of physical support. "They fear the loss of support of fixed principles which can be used automatically in cases of doubt," Cook charged, and hence they struck out wildly at those who pointed to the limits of human reason and suggested the true relativity to be found in reality. ${ }^{65}$

As most of the realists lost little of their confidence in science, so too they lost little of their ability to retaliate. Pound's condemnation of realism in light of his own earlier work, Yntema charged, "bears a tragic aspect of schizologic aberration." ${ }^{, 66}$ Fuller's legal theory, Patterson pointed out, was marred throughout by a pervasive ambiguity. "Surely the clarification of basic confusions does not hamper the exercise of the creative reason," he commented dryly. ${ }^{67}$ Myres S. McDougal, a young professor at Yale University, accused Fuller of "preaching pseudo-inspirational sermons." The day would come, McDougal hoped, when lawyers could be trained as scientific scholars "and not as priests in outworn and meaningless faiths whether of 'law' or of 'ethics." "68 Fred Rodell, another of the younger realists, charged that all those legal thinkers who spoke in sacred terms of some abstract "Law" had been "taught in mental goose-step." ${ }^{69}$ It was only appropriate to the spirit of much of the debate that Walter B. Kennedy, a leading Catholic scholar at Fordham University, returned the same charge in 194I by calling realism a "goose-step philosophy."

By 194I when America entered the Second World War, the bitter debate within the legal profession had reached its most intense phase, and it revealed a number of important facts about American thought in general and legal theory in particular. Most important, the debate demonstrated the depth of a basic split that divided two groups of American intellectuals who, for want of better terms, might be called scientific relativists and rational absolutists. On the one

65 "Walter Wheeler Cook," in My Philosophy of Law: Credos of Sixteen American Scholars (Boston, I94I), 64.

66 Yntema, "Jurisprudence on Parade," I 163.

${ }^{67}$ Review of Lon L. Fuller, The Law in Quest of Itself, lowa Law Review, XXVI (Nov. 1940), I72-73.

${ }^{68}$ Myres S. McDougal, "Fuller v. the American Legal Realists: An Intervention," Yale Law Journal, L (Mar. I94I), 840.

${ }^{69}$ Fred Rodell, Woe unto You, Lawyers! (2d ed., New York, 1957), 149.

70 "Walter B. Kennedy," in My Philosophy of Law, $151-52$. 
hand, the realists owed their inspiration and intellectual attitudes to a cluster of ideas associated with modern science. Truth was wholly dependent on empirically established facts and hypotheses, they agreed, and it was necessarily tentative and relative. On the other hand, the absolutists, such as Hutchins, Adler, and the Catholics, believed that human reason could discover certain universal principles of justice by analyzing philosophically the nature of reality. Deductive logic could demonstrate the truth of propositions and lead man to correct applications in settling particular, practical questions. The universal principles formed for the absolutists the basis for all ethical knowledge, which was demonstrably certain.

These two fundamentally irreconcilable attitudes were in large part responsible for the intensity and extremism in the debate. Since both sides started from widely divergent assumptions, they were often unable to understand, let alone sympathize with, their enemy's position. The realists saw rational absolutism as pointless and often subjected it to ridicule and scorn. Felix Cohen referred to it as "Transcendental Nonsense," while Arnold and Frank compared it to superstitious incantations chanted by witch doctors and faith healers. The rational absolutists returned the scorn in full, charging the realists with everything from atheism to Communism to nihilism. As the realists were often unable to understand how anyone could accept some of the canons of rational absolutism in light of the discoveries of modern science and philosophy, their critics were equally unable to see how any man could fail to accept that which was selfevident and necessary to give support to a universally valid ethical system. Such a system was necessary, they continually insisted, if men were to condemn totalitarianism rationally. With each side committed to its own obvious truths and faced with an implacable opponent, vilification and the questioning of motives became an almost automatic recourse. Those who would not see must have some hidden and unworthy purpose.

That deep division was also evident in the awkward positions taken by Pound, Fuller, Morris Cohen, and a number of other critics of realism. Such scholars knew the severe limitations of deductive logic and were committed to some form of legal empiricism. At the same time, however, they saw many of the theoretical problems realism created, and they agreed, when faced with the challenge of totalitarian ideology and practice, that some supralegal moral standard was necessary as the basis for ethical judgments. Torn between two conflicting attitudes, they tried desperately to reconcile them or to develop a coherent ethical position that would withstand the criticisms from both sides. Fuller's concept of natural law, for example, placed him distinctly outside the realist movement, but failed to bring him into any real philosophical agreement with the Thomists. It was too abstract for the one side and too positivistic for the other.

The long debate also clearly revealed the plight of ethical theory in the middle 
of the twentieth century. The incisive criticisms of modern philosophy and the dramatic impact of experimental science had made rational absolutism untenable in the minds of most educated Americans. Many were ready to conclude that moral justification in any ultimate sense was an impossible and meaningless concept. "Having surrendered the quest for certainty," Cook insisted, quoting Dewey, "we can offer no guarantees." 71 Though difficult to deny intellectually, that conclusion was dissatisfying to most Americans at the time when Nazism was perpetrating its outrages on both Germany and the rest of Europe.

The apparent success and spread of the totalitarian ideologies, backed by military might, exacerbated the internal division in American thought and placed the fundamental problem of the ethical basis of democracy into clear relief. The barbarity and repression evident in the various totalitarian countries enraged most American intellectuals. Feeling the deep need to condemn them in the clearest and strongest terms, they were forced to deal in some way with rationally based ethical judgments. That necessity created immense stress in the minds of many who either doubted the possibility of such judgments or found themselves unable to produce them. Some, like Becker and Malinowski, turned on much of their earlier work and argued that there were broad moral values that in fact did support the ideal of democracy and that showed equally that totalitarianism was evil. Others, such as Percy W. Bridgman and Stuart A. Rice, admitted that there was no ultimate ethical sanction for democracy and suggested only that human experience indicated that the great majority of men preferred it to Nazism. Most intellectuals finally had to ignore their doubts and the intellectual difficulties that plagued ethical theory and in the end simply assert the evil of totalitarianism and the relative goodness and desirability of democracy.

Although the Catholics in contrast expressed great certainty in the power of reason to discover ultimate principles, the debate revealed a defensive attitude on their part that at times reached extreme proportions. In spite of their fervent religious and intellectual convictions, they realized that they were fighting a battle against the ever-strengthening intellectual trends of the past three hundred years. Abstract rationalism simply could not stand against the combined forces of pragmatism, scientific empiricism, and modern critical philosophy. The vitriolic tone and extreme, unfounded accusations made against such movements as legal realism showed clearly the sense of intellectual frustration and institutional anxiety that underlay Catholic legal thought in the I930's. The identification of realism and relativism with totalitarianism was the ground on which the Catholics hoped to make their belated victorious stand against the intellectual forces of the twentieth century. Though they had some limited success during the time of most severe intellectual crisis in the late thirties and early forties, their counterattack failed, and the Catholics themselves eventually modified some of their more strident positions.

71 "Walter Wheeler Cook," 64. 
Finally, the debate suggested the course that American legal thinking would take in the years after the Second World War. While the idea of natural law grew somewhat in importance-and certainly proved useful for such purposes as trying war criminals-through the late forties and early fifties, it died down again and became mainly an isolated and parochial concept that enjoyed little support outside of a few Catholic law schools. Where it did have vitality it was made part of a broader empirical synthesis as in the work of F. S. C. Northrop. While ignoring some of its more extreme theoretical tendencies, the profession generally accepted many of the ideas associated with legal realism. That movement helped establish the importance of factual research in law, the necessity of empirical studies of the legal process, the legitimacy of a more flexible constitutional interpretation, and the acceptance of a pragmatic, operational concept of law. In spite of the problems the realists presented, both philosophically and legally, they were pointing toward the future by suggesting fruitful courses of study and more useful methods of analysis. The alliance the realists helped forge between legal theory and empirical analysis fortified the trend toward sociological jurisprudence that had begun forty years before and that was to become a commonly accepted part of American law in the years after the Second World War. 